This is an electronic reprint of the original article. This reprint may differ from the original in pagination and typographic detail.

Author(s): Meriluoto, Taina

Title: $\quad$ Turning experience into expertise : technologies of the self in Finnish participatory social policy

Year: $\quad 2018$

Version:

Please cite the original version:

Meriluoto, T. (2018). Turning experience into expertise : technologies of the self in Finnish participatory social policy. Critical Policy Studies, 12(3), 294-313. https://doi.org/10.1080/19460171.2017.1310051

All material supplied via JYX is protected by copyright and other intellectual property rights, and duplication or sale of all or part of any of the repository collections is not permitted, except that material may be duplicated by you for your research use or educational purposes in electronic or print form. You must obtain permission for any other use. Electronic or print copies may not be offered, whether for sale or otherwise to anyone who is not an authorised user. 
Author's original manuscript

The Version of Record of this manuscript has been published and is available in Critical Policy

Studies (2017) http://www.tandfonline.com/doi/full/10.1080/19460171.2017.1310051

Taina Meriluoto

PhD Candidate (Political Science)

Department of Social Sciences and Philosophy

University of Jyväskylä, Finland

taina.meriluoto@jyu.fi

\title{
Turning Experience into Expertise: Technologies of the Self in Finnish
}

\section{Participatory Social Policy}

\begin{abstract}
This article investigates the micro-level practices of subject-construction in Finnish participatory social policy. Through a governmental ethnography on projects that invite former beneficiaries to become 'experts-by-experience' in social welfare organizations, I discern the possibilities for freedom in the participants' self-construction. By making use of Michel Foucault's conceptual tools of care of the self and confession, I illustrate how, contrary to the projects' emancipatory promise of providing the service users the freedom to reconstruct themselves, the projects entail practices that curb the participants' way of 'knowing themselves'. They require the service users to reframe their raw experiences as neutral and objective knowledge, making alternative ways of knowing appear 'irrational', and hence easily discountable. I conclude that despite the user involvement initiatives' promise of incorporating different forms of knowledge, the participants are in practice required to realign their way of knowing with the dominant knowledge paradigm in order to be accepted as participants.
\end{abstract}

Keywords: Expertise-by-experience, governmental ethnography, service user involvement, technologies of the self, truth-telling, care of the self, participatory policies 


\section{Introduction}

Over the past twenty years, a widespread participatory dogma has come to shape public policy-making (e.g. Polletta 2016; Saurugger 2010). Emerging in the crossroads of participatory and deliberative ideals of democracy, and the neoliberal ideology with its calls for increased individual responsibility, the project of making people more selfreliant, active and contributing has become an extremely compelling direction for policymakers (Eliasoph 2016; Polletta 2016; Sørensen and Triantafillou 2009, 4-5; Neveu 2007).

In social policy, this ethos has translated into the idea of service user involvement (e.g. Barnes and Cotterell 2012a). By encouraging people to participate, it is hoped that more empowered, and consequently healthier, more reliable and more cooperative citizens will be constructed (Lister 2002, 39; Eliasoph 2016, 254; Gaventa and Barrett 2012; Perälä 2015). In addition, by incorporating the service users' 'local knowledge' into decision-making, the goals of cheaper and more efficient services as well as more legitimacy for governance are sought after (Nez 2016; Demszky and Nassehi 2012, 174; Fledderus, Brandsen, and Honingh 2014).

Previous studies on participatory initiatives in general, as well as service user involvement schemes in particular, have pointed to the governmental capacity of the projects (e.g. Wilson 2001; Fox, Ward, and O’Rourke 2005; Leppo and Perälä 2009). These studies have shown how participatory projects construct their participants' subjectivities in specific ways in order to meet the projects' varied objectives (e.g. Gourgues, Rui, and Topçu 2013; Charles 2016, loc. 19; Barnes, Newman, and Sullivan 2007, 63-70; Newman and Clarke 2009, 138-139). Previous empirical research on participatory initiatives has focused primarily on what characterizes the subjectivities, or the type of participation, towards which the participants are being conducted (e.g. 
Charles 2016; Newman and Tonkens 2011) and on the diverse objectives set for the projects, as well as the rationales underpinning them (Ganuza, Baiocchi, and Summers 2016; Dagnino 2007; Barnes, Newman, and Sullivan 2007; Gourgues, Rui, and Topçu 2013). Thus far, less attention has been paid to how the initiatives work on their participants' subjectivities — techniques that $\operatorname{Kim} \operatorname{McKee}(2009,478)$ calls 'the micropractices of local initiatives'.

This article responds to the recent call for more micro-scale, empirically grounded governmental analysis to scrutinize the initiatives' ways of working (see e.g. Polletta 2016; Brady 2016; McKee 2009). The article's purpose is to flesh out the specific techniques and practices of subjectivation, (Foucault 1994, 785) employed in user-involvement projects that introduce former beneficiaries as 'experts-by-experience' into social welfare organizations in Finland. These projects are treated as practical examples of participatory governance, seeking to 'activate' former service users by forging new, active identities for them. The article provides a micro-scale analysis of the initiatives' 'art of governing' (McKee 2009, 473) by asking how they influence the self-construction of their participants. Through a governmental analysis of the often mundane, everyday practices, I hope to shed light on the actual processes of subjectivation, where the participatory governmentality is interpreted, enacted and responded to (see Brady 2016; Fridman 2014, 92).

As expertise-by-experience is a role created on the basis of certain previous experiences and their particular type of use, personal history becomes a key resource of governance and subject-formation. Hence, the article focuses on how the participants' past and the stories they tell about themselves are operationalized as tools of governance. I employ Michel Foucault's concepts of care of the self and confession (Foucault 2012) as analytical tools to illustrate the practices that delineate how the 
participants reconstruct themselves through the initiatives, and to critically examine the participants' possibilities for freedom in this process. The article asks how the participants' freedom is restricted, and in turn expressed, in the practices of selfconstruction.

The article's main argument is that, in the initiatives studied, the participants' self-construction is steered particularly through practices that define knowledge and expertise. More precisely, as the object of expertise in this particular case are the participants themselves, the key techniques of governance are those that define when a person knows oneself. Hence, I posit, the participants' subject-construction is steered 1) by delineating the practices the participants need to undergo in order to 'know oneself', and 2) by defining the signs the participants need to manifest to be considered 'knowing themselves'. The article then shows how 'expertise over oneself' is constructed as a synonym for knowing oneself according to the dominant paradigm of knowledge, making alternative ways of articulating oneself appear as 'irrational'. As a result, contrarily to the projects' emancipatory promise, the projects' practices can be seen as curbing the participants' freedom.

The article begins with a discussion of the current literature on expertise-byexperience, and the consequently changing notions of expertise and agency in social welfare. Next, I introduce Foucault's notions of subjectivation, and discuss how the process of subject-construction has previously been studied in the context of social services. After presenting my conceptual tools, methodology, data, and the context of the Finnish case, my analysis focuses on the practices used to steer the processes the participants undergo to 'know themselves', and their acts of resisting the practices. I end with a discussion considering the implications the identified governmental processes have for the debate on service user involvement. 


\section{Expertise-by-experience in Social Welfare — Transforming Expertise,}

\section{Renegotiating Agency}

Expertise-by-experience as a concept and a practice has been traced back to the "third way' health and social care reforms in the UK, which sought to craft a new, active role for the service user (Barnes and Cotterell 2012a; Fox, Ward, and O'Rourke 2005; Wilson 2001; Tehseen 2013). Similarly to many other participatory measures, these service user involvement initiatives were introduced as a response to an array of problems - both social and economic (Newman and Clarke 2009, 134-139; Barnes and Cotterell 2012a; Lewis 2010, 277-278; Stewart 2013). By inviting service users to participate in the planning and execution of social services, they were to become 'empowered', and assume more responsibility over their own life and care (Healy 2000). In addition, (and in part through the participants' greater responsibility over themselves) the co-produced services were to be more efficient, and consequently less costly (Wilson 2001, 136-137; Barnes 2009, 219-220). Furthermore, through service user engagement, the new 'duty' (Barnes and Cotterell 2012a, xviii) of public involvement was met, making public governance more legitimate as it adhered to the new participatory norm (Leal 2007).

Service user involvement has also received criticism, pointing particularly to the conflicting purposes given to the initiatives. While on one hand, the participants have been shown to engage in user involvement schemes with hopes of having an impact on the services and attitudes they have experienced as harmful (Barnes and Cotterell 2012b; Wilson and Beresford 2000), public administration has not always been keen to incorporate the knowledge of these new experts. Instead, it has emphasized the 'therapeutic' and 'empowering' functions of participation (Barnes 2009, 224; Yiannoullou 2012). Expertise-by-experience has even been accused of co-opting the 
civic activism of the survivors' movement, introducing talk of networks and partnerships, but then 'taming' the survivors' attempts of advocacy, hence undermining the activists' efforts to make their voices heard (Beresford 2002, 96; Tehseen 2013, 50$51)$.

Consequently, negotiations on the role and authority of service users have turned into central power struggles within the social services (Newman 2005; Tehseen 2013; Powell et al. 2009; Wilson 2001; Fox, Ward, and O'Rourke 2005; Leppo and Perälä 2009). A key notion in these battles is the concept of expertise (Krick 2016; SmithMerry 2012; Fledderus, Brandsen, and Honingh 2014, 426-428; Barnes 2009). Through its redefinitions - as it is now the users who are 'the experts of their own lives' experience has become an increasingly powerful source of authority (Blencowe, Brigstocke, and Dawney 2013, 4; Demszky and Nassehi 2012, 172). More emphasis is now put on the service users' 'lived knowledge', both as a means of gaining valuable information on the structural inequalities and local contexts affecting the service users' lives, and as a way of empowering them and making them feel valued (Healy 2000, 2930; Nez 2016; Randall and Munro 2010, 1495; Närhi 2004, 54-55).

However - and this should be emphasized — in service user involvement schemes, the service users' knowledge is most often referred to as 'secondary' or 'alternative' knowledge, hence implying that they serve a complementary role. Their expertise is often defined as being of a practical nature, adding something valuable, but not fundamental to the discussion. 'First knowledge' is situated elsewhere, allowing the secondary knowledge to be evaluated vis-à-vis it (Barnes and Cotterell 2012a, xv-xxvi, xxi; Healy 2000, 40-42). Furthermore, it has been noted that the participants are often invited to take part based on their experience-based knowledge, but are required to transcend their personal views when actually engaging in activities of participatory 
governance in order for their participation to be considered legitimate (e.g. Lehoux, Daudelin, and Abelson 2012; Neveu 2011, 151; Thévenot 2007, 420). Negotiations over knowledge — on whose and what kind of knowledge counts — are thus key sites of power struggle in participatory social welfare.

The question of knowledge as the basis for the right to participate has a particular significance in the context of service user involvement. As the object of knowledge is the participants' own lives, the definitions of knowledge become questions of 'knowing yourself'. Hence, truth, knowledge and self-construction become intertwined in a particularly explicit way. The notion of being an expert of yourself emerges as a prerequisite for participation, allowing definitions of expertise to be used as a governmental device to steer the subject-construction of the participants.

Consequently, the situated negotiations concerning the conditions for possessing an expertise on oneself become extremely interesting. When is one considered to be an expert? Conversely, can one not be an expert of her own experience? And moreover, how should one cultivate oneself to become such an expert? To elucidate these questions, I introduce Michel Foucault's thinking on subjectivation, and his conceptual tools that connect subject-formation with truth-telling.

\section{Technologies of the Self in Participatory Social Policy}

In Michel Foucault's thinking, subjects are constructed at the juncture between outside attempts to define the individual, and her own interpretations and responses towards those definitions (Foucault 1994, 718-719; also Kelly 2009, 100-101; Rose 1999, 11; Ball and Olmedo 2013,87). Consequently, his notion of technologies of the self has provided the basis for many analyses of power in contemporary social work and therapeutic practices that work to (re)construct the subjectivities of their 'targets' (e.g. 
Randall and Munro 2010; Dawney 2011; McFalls and Pandolfi 2014; Besley 2005).

Technologies of the self has proved a useful analytical device particularly when examining liberal forms of government, as it emphasizes the active role of the individual whose subjectivity is being worked on (Foucault 1994, 785; Faubion 2014, 5-6; Fridman 2014, 92). As opposed to a passive object of subjection, the subjects under liberal forms of government need to be willing to actively work on themselves, 'get to know themselves', share this knowledge of themselves, and engage in its critical examination and cultivation (Foucault 1982, 783; Foucault 2012, 219-235; Dawney 2011, 547; Powell and Khan 2012, 134-135). Here, participatory practices are understandably extremely compelling. They provide a concrete toolkit for the participants to become engaged in their own governance (see Newman 2005, 122; Gourgues, Rui, and Topçu 2013, 12; Perälä 2015).

The Foucauldian idea of self-governance (esp. Foucault 2009; Kelly 2009, 99102) entails two core practices: knowing oneself and cultivating oneself - e.g. training one's emotions and mastering one's passions (Randall and Munro 2010, 1494-1496). Through them, one is thought to establish an active relationship towards oneself (Kelly 2013). This 'working with oneself' is one of the primary tools and promises of participatory social policy. Participatory social work uses concepts such as 'selfdiscovery' to illustrate the various practices through which one 'works with oneself' in order to 'reach one's full potential' (e.g. Randall and Munro 2010; Dawney 2011; McFalls and Pandolfi 2014; Langer and Lietz 2014, 124).

Previous studies have noted the paradox this emancipatory promise of liberal government entails (e.g. Heyes 2007; Fox, Ward, and O’Rourke 2005; Wilson 2001). In Rose's, O’Malley's and Valverde's words $(2006,89)$ 'The subjects so created would produce the ends of government by fulfilling themselves rather than being merely 
obedient, and would be obliged to be free in specific ways' (my emphasis). The liberal project of subjectivation, it is suggested, operates by providing environments and techniques for self-development and discovery, but then uses these processes of selfcultivation to steer the subject towards 'the normal' (Heyes 2007; McFalls and Pandolfi 2014, 168-187; Dean 1999, 75-76; Healy 2000, 44). As Fox, Ward and O’Rourke (2005) put it to become an 'expert-patient' is a 'double-edged sword': 'it is to be empowered to manage one's health and illness, but to adopt this power from a dominant disciplinary system of thought'. ${ }^{1}$

A crucial question for the investigation of participatory welfare practices, then, is whether, and to what extent, the participants can express freedom in their selfgovernance. While some scholars argue that the trendy participatory practices of social policy offer the promise of freedom through self-discovery (see Perälä 2015), others see them as limiting and normalizing, conditioning the process of self-cultivation through outside norms (e.g. Wilson 2001; Fox, Ward, and O’Rourke 2005; Dawney 2011; Langer and Lietz 2014, 194-198). In this article, I propose to investigate this emancipatory paradox through an analysis of the concrete practices that direct the service users' self-construction at the micro-level. Through a detailed description of the technologies of the self, identified in the user involvement initiatives, it becomes possible to provide a nuanced investigation into the participants' possibilities for freedom in self-cultivation. As my analytical tools, I employ Foucault's notions of confession and of care of the self, which are discussed in the following.

\footnotetext{
${ }^{1}$ Cressida J. Heyes $(2007,37)$ questions the idea that the normalizing practices either limit or enhance the subject's freedom. Instead, she suggests that while the practices certainly are used to construct docile, 'normal' subjects, it is possible that people may willingly choose to follow them and cultivate themselves in a way desired by the administration, in an attempt to 'feel normal'.
} 


\section{Methodology: Interpreting the Practices of Self-construction}

In his later lectures, Foucault argued that, in practice, the government of the self takes place through 'regimes of truth' (Foucault 2012, 91-92; also McFalls and Pandolfi 2014, 173-174), meaning the practices and institutions that define what is considered the truth, and when one is considered to be telling it (also Brion and Harcourt 2014, 298; Rose 1999, 4; Dean 1999, 18). As one gets to know oneself by being honest with oneself — and makes oneself knowable (and governable) to others by telling the truth about who they are (Foucault 2012, 221) — the definitions of truth become powerful tools in influencing people's self-governance.

I employ Foucault's historical concepts of care of the self and confession to illustrate the different practices connecting truth-telling and subject formation in the user involvement initiatives, and to critically examine the participants' possibilities to express freedom in their self-formation. What interests me are the practices that aim at defining how the participants' previous selves are expected to be worded, or made knowable, in order for them to be considered 'knowing themselves'. At stake in these practices are how the 'truths' is conditioned (meaning what kind of stories are accepted as knowledge over oneself) and how one is required to position oneself towards that story in order to be accepted as a participant. Viewing the practices identified against Foucault's thinking on confession and care of the self as different logics of selfconstruction makes visible how the participants' self-construction may be constricted and how, in turn, freedom in self-construction would be possible.

Foucault presented the notions of care of the self (souci de soi, epimeleia heautou), and confession as parts of the same historical continuum of 'practices of subjectivity' (Foucault 2004a, 10; also Iftode 2013). Both rely on techniques that 'steer the subject's gaze inward' - i.e. that require and enable the subject to know and to 
cultivate herself (Foucault 2004a, 254-256; Fornet-Betancourt, Becker, and GomezMüller 1987, 116-117). Their core difference lies in their contrasting positions towards the subject's freedom. Care of the self, as a pre-Christian practice of self-cultivation, regarded self-construction as a practice of freedom (Foucault 2012, 232-234; 2004a, 132-133; see also Fornet-Betancourt, Becker, and Gomez-Müller 1987; Kelly 2009, 100-102). It represented a manner of self-making that enabled the subjects to be 'artists of their own lives' (O'Leary 2006, 121), to cultivate themselves free from definitions of truth and externally defined norms(Iftode 2013, 82).

The Christian hermeneutics of the self, says Foucault, take up these techniques of knowing and cultivating oneself, but couple them with an aspect of self-renunciation (Foucault 2004a, 255-257; Iftode 2013, 78). Foucault argues that confession is a mode of self-cultivation that requires revealing and evaluating oneself according to norms 'from above', transforming oneself by adhering to this outside moral paradigm (Foucault 2004b, 186-187; 2012, 220-221; 2004a, 186-187; also Kelly 2009, 94). This pastoral type of power adopt the pre-Christian techniques of self-cultivation, but instead of using them as tools to enhance the subjects' freedom in 'modeling their own statues' (O'Leary 2006, 54), they use them to curb and steer the process of self-making (Foucault 1982).

Contemporary studies of welfare practices have employed Foucault's conceptual tools to critically discern their play on the participants' freedom (see e.g. Wilson 2001; Randall and Munro 2010; Perälä 2015; Heyes 2007; Dawney 2011). These studies employ care of the self as an analytical device to illustrate the practices that allow the participants to exercise freedom through self-formation (e.g. Perälä 2015; Heyes 2007; Ball and Olmedo 2013), as opposed to the normalizing governing practices that steer participants' self-formation through outside norms (see Randall and Munro 2010; 
Besley 2005). Confession, in turn, has been used to illustrate how therapeutic practices in particular steer persons in the way they cultivates themselves by creating 'a rupture' between one's past and future self (e.g. Besley 2005, 373; Dawney 2011, 547), requiring the subject to submit herself to be governed within the dominant paradigm of knowledge (Foucault 2004a, 98; Besley 2005, 374-375; Besley 2002, 134).

In this article, I consider confession and care of the self as contrasting logics of self-construction (see Foucault 2004a, 212). Confession, requiring subjects to transform themselves into 'what they ought to be', is used to make visible the practices that require the participants to work upon themselves to adhere to outside ideals and standards. Care of the self, in contrast, is used to illustrate an alternative means of knowing oneself that does not require one to seek outside ideals in the dominant system of knowledge, but instead allows one to construct oneself freely (Foucault 2004a, 8386, 134-135; see also Heyes 2007, 113-117). The concepts in this article are used to ask whether it is possible for the participants to 'know themselves' in other ways than through the route sketched out by social care administrators. the administration?

My micro-level analysis responds to Michelle Brady’s call for an ‘ethnographic imaginary' (Brady 2016) in governmentality studies. Brady argues that such studies give the researcher 'greater insights into the multiplicity of power relations and practices within the present, as well as the actual processes through which subjectivities are formed' (Brady 2014, 12; also Teghtsoonian 2016). While traditional governmentality studies are interested in political rationalities and ambitions, a governmental ethnography asks how these rationalities are made practical, how they are interpreted, perceived, responded to and resisted in concrete programs, techniques and ways of working (Teghtsoonian 2016; Brady 2011; Brady 2014, 11-33; McKee 2009; Li 2007a). Kim McKee maintains that this perspective helps to avoid attributing a false 
coherence to political rationalities and programs of governance, revealing instead their ‘messiness', situatedness, struggles and multiple possible consequences' (McKee 2009, 478-479; also Brady 2011, 267; Fridman 2014, 94; Lippert and Brady 2016).

The ethnographic approach, I posit, is particularly well suited to examine practices of subject-formation, as it allows paying attention to the possibilities of interpretation, adaptation and resistance of the governed (also McKee 2009, 479; Fridman 2014; Larner and Moreton 2016, loc. 1319-1327). By focusing on practices and moreover on how the practices are interpreted and experienced, I am able to investigate 'the inevitable gap between what is attempted and what is accomplished' (Li $2007 \mathrm{~b}, 1)$. As the essence of governmental thought is in the play on the freedom of those governed, to merely investigate the policy documents would neglect the very essence of governing through individuals' freedom.

\section{Context and Data}

Expert-by-experience emerged in the Finnish social sector as a new concept at the turn of the $21^{\text {st }}$ century. Following a participatory shift in norms of good governance in Finnish public policy, the new policy outlines stressed the importance of active citizen engagement (Salminen and Wilhelmsson 2013, 10-11), and pushed towards new innovations to involve and activate citizens, particularly among the 'marginalized' citizenry (see e.g. the National Development Program for Social Welfare and Health $\left.\operatorname{Care}^{2}\right)$.

Following suit on examples from the UK and Denmark, Finnish mental health organizations started to recruit and train former service users to become experts-byexperience in service production and policymaking. The concept and practice then

\footnotetext{
${ }^{2}$ http://stm.fi/en/article/-/asset_publisher/the-kaste-programme-s-client-oriented-reforms
} 
disseminated fast and widely among health and social welfare organizations in both the public and the third sector (Rissanen 2015, 201). As it stands, the popular term is used to signify a variety of people and activities. Most commonly, experts-by-experience act as consultants in service development, as peer supporters, or in public advocacy based on their personal experiences.

This article draws on themed interviews with 23 experts-by-experience and 14 social work professionals from seven projects ${ }^{\mathrm{i}}$ that are developing expertise-byexperience in the Finnish social welfare sector. ${ }^{3}$ The interview data is complemented by policy documents on expertise-by-experience, produced by the projects as well as their funders. ${ }^{4}$ In addition, I draw on my ethnographic observations as a practitioner in one of the NGOs studied. Between 2011-2014, I participated in, and organized, training sessions, meetings and workshops on expertise-by-experience with experts-byexperience and with practitioners, both within the NGO where I was employed as well as with its partners.

The projects studied were either run by public sector organizations (2) or NGOs (5), and all received public funding. They all work within the area of adult social work, focusing on issues like domestic violence, gambling, homelessness, mental health and substance abuse. In broad terms, the projects presented two objectives for expertise-byexperience: the inclusion and empowerment of marginalized services users, and the introduction of experience-based knowledge into public decision-making. Out of the

\footnotetext{
${ }^{3}$ I conducted the interviews between 4 April 2014 and 16 October 2015 as results of openended invitations sent to the projects. The interviews were conducted in Finnish and the excerpts were later translated into English by the researcher.

${ }^{4}$ Documents include the projects' own material concerning expertise-by-experience, and the funders', particularly the Ministry of Social Welfare and Health's key documents sketching out the policy.
} 
seven projects, six invited the experts-by-experience to act in and through their own organizations, while one was focused on 'producing' experts-by-experience for the needs of other organizations in the social welfare sector. Crucially for the premises of this article, the impetus for introducing the policy of expertise-by-experience was in all of the cases, as Warren (2009, 3-13) would put it, 'governance-driven'. Consequently, both the objectives and the practices of the projects, steering the participants' subjectconstruction, were mostly defined by the administration.

Except for the project that trained the experts-by-experience for other organizations' use, all of the experts-by-experience interviewed had prior connections to their respective organizations. All but one were former beneficiaries. They had become engaged in the projects through varying ways: 12 had actively applied for training, five were invited — or 'lured' as one expert-by-experience put it — and six felt that they were doing the exact same things they have been doing all along, only now under a different name. Seven of the experts-by-experience interviewed were employed in the organizations, 12 performed paid 'gigs' when invited, and four acted on a completely voluntary basis. The professionals, for their part, all worked in projects tasked with developing expertise-by-experience in their respective organizations. Their positions ranged from project employees to executive directors.

The interviews took place at a time when the concept and policy of expertise-byexperience had rapidly gained in popularity. As new organizations working in various fields started to adopt the concept and translate it into their own cultures, a plethora of conflicting interpretations on the projects' purpose and ways of working arose. Many of the interviewees were well aware of these conflicts, and presented strong views on what things should be like. Many interviewees were also openly critical of the practice, pointing to the potential pitfalls, such as participant selection, in the projects. 
The data was analyzed following a method of close reading (see Yanow 2015, 404). First, I identified the different requirements for experts-by-experience expressed in the data, as well as the practices — such as training and interviews — described as necessary for someone to be able to act as an expert-by-experience. After having thematically grouped the requirements and the practices, I discovered that all focused on the correct form and position of the personal stories of the experts-by-experience. Consequently, I placed the participants' personal stories as the focal point of my analysis. I asked how the service users' stories of themselves are shaped in the projects, and what are the characteristics of a story that is accepted as 'the truth' in this context.

\section{Governing Personal Stories}

In the following, I will present the techniques used in the projects to delineate how the participants 'know themselves'. I start by presenting the emancipatory promise of the user involvement initiatives. This promise of the initiatives as sites for the "care of the self' is then critically examined by presenting the concrete set of practices of selfgovernance employed in the projects. The final section of my analysis focuses on the participants' possibilities for resistance.

\section{The Emancipatory Promise - User Involvement Initiatives as Sites for 'Care of the Self'}

A major promise, and one of the strongest appeals of expertise-by-experience according to my interviewees, was the possibility of 'building a new identity'. Expertise-by-experience carried with it a promise to 'turn the painful experiences into a strength'. In many instances, the user involvement initiatives were marketed as sites for 
self-discovery and means of 'self-actualization', as presented in the following citation from a guidebook for developing expertise-by-experience:

Expertise-by-experience is empowering because it carries with it a feeling of significance of one's painful experiences. In expertise-by-experience, the participants can feel included and build a new identity for themselves. They gain a possibility to have an impact and develop themselves in issues that matter to them. ${ }^{5}$

This promise is analogous to 'care of the self' as a practice of freedom. The projects are presented as sites of 'building a new identity' rooted in one's own, significant experiences. The process is presented as free and liberating, with the professionals merely providing 'the necessary resources', as the following project report illustrates:

In recovery-oriented services, the central theme is to increase an individual's power in their own lives, and hence support their agency. The relations of care are equal, and instead of an expert-patient -setting, the professional positions herself rather as a coach or a partner. The experience-based knowledge of the service user is valued. - The point of departure is always in the service user's own goals not in recovery defined from the outside. The role of the professional is to provide the service user with the necessary resources, such as knowledge and skills, networks and support that enhance their abilities to govern their lives. ${ }^{6}$

\footnotetext{
${ }^{5}$ Opas kokemusasiantuntijatoiminnasta [A Guide to the Practice of Expertise-by-experience]. Hietala, Outi \& Rissanen, Päivi. 2015. [Kuntoutussäätiö \& Mielenterveyden keskusliitto / The Rehabilitation Foundation and the Finnish Central Association for Mental Health].

${ }^{6}$ Kuntoutujasta toimijaksi - kokemus asiantuntijuudeksi. [From a survivor to an active agent experience into expertise]. Working paper 39/2013, p. 10-11. National Institute of Health and Welfare.
} 
The projects' promise is thus extremely emancipatory. Next, I turn to the concrete practices of 'self-development', and investigate them against this emancipatory claim.

\section{The Projects' Practices of Governance}

Five of the seven projects studied offered training to their participants as a pathway from the role of a service user towards the role of an expertise-by-experience. These varied significantly in length, ranging from a six-day course up to a two-year process with 'on-the-job training periods' in between. They also varied in their selectiveness of the participants: in three organizations, everyone willing would be able to participate, whereas two projects interviewed and selected 'students' who were considered 'to have the aptitude' to take part in the training. However, in the three organizations with 'open' training, a selection process also took place before the experts-by-experience were allowed to act outside their home organizations. Quite concretely, based on their observations, the professionals selected the participants that they considered to be ready and provide 'the best fit' for a particular task. Hence, before the experts-by-experience were granted the possibility to claim their new role, their 'readiness' to participate was evaluated either in the context of the training or before proposing tasks that involve sharing their experiences in public.

A similar process was present in the two projects that did not require training for their participants. Even though the actors in these projects were rather openly against training of any kind, claiming that they 'strip the experience of its value', as put by an expert-by-experience in an NGO, they too placed a filter between the projects' home organizations and the outside public. Everyone was indeed welcome to act as an expertby-experience inside the organizations, but certain requirements had to be met before the participants were considered 'ready' for public participation. 
A common feature in all of the training-processes, as well as the other practices determining the 'readiness' of the participants, was that they placed a strong emphasis on 'working with one's story'. All of the training-processes included a section where the participants' life's story was laid down, rearranged and represented. In the following, I will examine in detail the practices the experts-by-experience are required to undergo in order to be considered to know themselves enough to be 'experts of themselves'.

\section{Getting to Know Oneself}

The first stage in the participants' process towards becoming an expert-by-experience is 'facing one's past'. The ability to reveal one's past fully is positioned as the condition of 'truly knowing oneself' (see also Foucault 2004a, 334). The following interviewee describes how talking about one's experiences is the first, necessary step towards becoming an expert-by-experience, and considered proof of both the on-going process of facing the past, and the increasing level of 'self-awareness' resulting from this process:

$\mathrm{TM}^{7}$ : Does expertise-by-experience require something?

E4: Well, the experience. And maybe someone to talk to about it in order for the issue to start to resolve. I believe that you have to be able to talk about it.

TM: So even though you have the experience but don't talk about it, you are not yet an expert-by-experience?

E4: Yes. It's really hard to define. But the way I see it, an expert-by-experience talks about her experiences, if only to one person alone.

\footnotetext{
${ }^{7}$ In quoted interviews, the abbreviations E1-E23 refer to the experts-by-experience, P1-P14 to the professionals and TM to the interviewer.
} 
This process of 'facing one's past' is in large part similar to Foucault's ideas about the confessional as a technology for rendering oneself knowable, governable and ready for a new, improved subjectivity. As noted, the process of subject-formation through truthtelling can be influenced by defining the criteria it has to meet in order for it to be considered as truly revealing 'the truth' about the person. In these initiatives, true selfawareness and self-discovery was defined to manifest when one can talk about one's past honestly and thoroughly, without shying away from passages that evoke awkward or painful emotions. The following interviewee, an expert-by-experience in the public sector, describes how omitting certain passages from one's life story should be considered a warning signal of someone not facing one's past fully, and hence not able to cultivate oneself in the way expected:

TM: I'm extremely interested in the part of the training where you dealt with your life stories. Could you describe it a bit more? What happened there concretely and what do you think was its goal?

E18: Well, we wrote it down, and after we had done that, we read the stories aloud to each other, if not entirely, then at least the parts you wanted to share with the others. And then we reflected on them, on how it felt to tell and write the story. I think the point was that even though you don't need to share everything you've written, if your paper is full of stuff that you are not ready to share, maybe you still have some processes that are unfinished.

If one cannot meet the criterion of full disclosure, one cannot be considered 'ready' to become an expert-by-experience. Consequently, as one starts the journey towards becoming an expert, one has to manifest the will and ability to encounter one's past bravely and fully — preferably in the context of the projects' training sessions. By so doing, one also lays oneself bare in front of others in the form of a narrative, ready to be 
conducted towards a new and improved self.

\section{Becoming an Expert of Oneself}

After having been proved ready to 'work with one's story', the past that has been opened up for scrutiny is rearranged. This is where the 'raw experiences' get turned into 'expertise', as the following quotes from a policy document and an NGO practitioner illustrate:

The training for experts-by-experience in the Key to the Mind project was an eight months long process, during which the students were offered the possibility and the tools to work their raw experiences into expertise. ${ }^{8}$

TM: Why is dealing with your past important?

P9: Well, it is precisely the expertise of the expert-by-experience. I mean, that she has organized her experiences. She will probably have had many tools to do it, therapy, for example, training and peer support also. It distinguishes experiencebased expertise from other experience-based knowledge. I mean, everyone has experience-based knowledge and that of the service users needs to be exploited, but it isn't necessarily so organized and thought through, but instead some raw form of knowledge.

This is a crucial departure from the projects' promise of providing a free space for recreating oneself. Instead of giving value to the 'raw experiences' as a basis for subjectformation, they need to be worked upon under the dominant paradigm of knowledge in order to be considered 'the truth'. In practice, this entailed two interwoven

\footnotetext{
${ }^{8}$ Kuntoutujasta toimijaksi - kokemus asiantuntijuudeksi. [From a survivor to an active agent experience into expertise]. Working paper 39/2013, p. 22. National Institute of Health and Welfare.
} 
requirements: distancing oneself from one's experiences (also Langer and Lietz 2014, 192), and reframing the experiences as a source of knowledge by transferring and comparing them to other knowledge available on the matter. Seventeen out of the 23 experts-by-experience, and 13 out of the 14 professionals interviewed used the terms 'repositioning oneself' towards one's story, or 'reorganizing one's story' when describing what was required of the participants in order to claim their new role as an expert-by-experience. The following transcript demonstrates this concretely. Here, a professional from the public sector talks about how gaining 'additional knowledge' and 'analyzing one's experiences' in relation to it are presented as requirements of 'knowing yourself':

TM: You said that there's a difference between the trained and the non-trained experts-by-experience. What is the difference?

P4: Well, the fact that they work very thoroughly with their own story. But also that they acquire so much theoretical knowledge that they get possibilities to reflect on their experiences in a larger context. I think it helps to see different sides of things. And my experience is that, our 86 trained ones, they work in a very smart way out there. They have a lot to offer and I think it's related to the fact that they have been able to reflect on their own stories over time and have received additional knowledge that has helped them analyze their experiences. That's why they have very mature thoughts about many things.

One's correct form of 'knowing oneself' was, hence, evaluated using the same criteria for 'reliable knowledge' as for other forms of expert-knowledge. Quite concretely, one had to manifest an expert-position towards oneself in order for one's knowledge on oneself to be accepted as the truth. Signs of such an expert-relationship towards one's 'raw experiences' were defined by the concepts of distance and neutrality; 'you have a 
certain amount of air between yourself and your experiences', is how a professional in an NGO put it. 'You have to be able to talk about your experiences without talking about yourself' said an expert-by-experience in the public sector. This demand for neutrality is visible in the following quote from an expert-by-experience in an NGO, where a sign of having 'sufficiently' dealt with your past means 'no longer' being overemotional or uncontrollable, but already calm and neutral.

TM: What does it mean that the past has been dealt with?

E17: [sighs] Well, I think that dealing with your past means that you are able to talk about it without big emotional reactions, I mean that you don't burst into tears or feel very angry or bitter, but you are able to talk about your experiences in a calm and neutral manner. I mean that your emotions are no longer uncontrollable. And that you have constructed your story into a whole where you already understand the connections between the facts.

The call for neutrality sets a normative condition for credible knowledge, and consequently, the legitimate form of being for the expert-by-experience. If one is too emotional or too passionate, one is considered 'too attached' to one's experiences, or 'not seeing the whole truth', and consequently not qualified for participation. The ability to deliver one's message within the norm of neutrality is deemed a sign of stability. In contrast, failure to do so is labeled a sign of mental instability, which consequently justifies dismissal of the person's message (see also Martin 2011, 166168). As a result, a disconnect between the projects' promise and its concrete practices, a contradiction ever-present in expertise-by-experience, emerges: the demand for 'raw' experience and the processing of that experience. The projects' promise to value and cherish everyone's 'pure' experiences, and to provide a free space for self-cultivation based on them, is in practice curbed through demands that define when a person is 
considered to 'know herself', be in command of herself and tell the truth about herself. Even though it is the strong personal experiences that creates the possibility for someone to become an expert-by-experience, one has to turn those experiences into knowledge according to specific demands in order to be considered a competent and legitimate participant.

\section{Possibilities for Resistance}

Interpreting projects such as expertise-by-experience as always succeeding in influencing subjects as intended is, of course, far too simplistic. In the last part of my analysis, I will focus on forms of resistance that can be mounted against the practices sketched above, by discussing first how one can refuse to prove that one has dealt with one's experiences in the expected way, and second, how one can resist representing one's experiences in a way expected by the projects. These acts of resistance, although rare, were nonetheless present particularly among the NGO projects studied.

If we maintain that the process of diligently going-through and reframing one's past as 'knowledge' is the key tool of governance in expertise-by-experience, one of the most obvious ruptures manifests when one refuses to take part in activities where such a process could be directed and proven. In the following quote, an expert-by-experience from an NGO questions the process of reframing one's experiences as knowledge:

E1: Personally I would never go to a training for experts-by-experience.

TM: Why not?

E1: Well what kind of experience can I learn from school? Then it would be like reading a book. For me, expertise-by-experience is something that relies entirely on my own experience, my own life that I've lived. It is my life. I know what I'm talking about when I talk about my life. I don't understand what part of it I could possibly study. 
By questioning the training provided, the interviewee critiques the demand to turn experiences into a certain form of expertise defined through outside norms. Instead, she underscores the value of the experiences as such, hence claiming ownership over their interpretation and her own self-making.

Another manner of resistance is the refusal to comply with the norms set for appropriate representation of one's past. The following quote is a rare one indeed, expressing a fierce will of an NGO's expert-by-experience to determine his own manner of saying and being:

E23: This is my thing and no one else needs to direct it. --- I think that I should be allowed to say what I have on my mind and not have to polish it. I think that it's useless to speak if you can't say it the way you experience it.

Such parrhesiastic subject-formations were extremely rare in my data. More commonly the interviewees described how their manner of representing themselves was limited through demands for appropriate knowledge and discourse. The following NGO expertby-experience illustrates this by describing a struggle where his obligations towards the other beneficiaries restrain him from challenging the norms set for experts-byexperience:

TM: You joked earlier that you could say pretty much anything as long as it's not offensive to the funder. Are there limitations to what you can do?

E12: Yeah, I can't say some things because of the organization. Like, once they asked me if I wanted to destroy the organization. Well, I don't because then there'd be no one who would defend the John Does on the street.

Here the significance of meeting the conditions of the right way of knowing become vividly clear: if the conditions of the correct way of speaking are not met, the opinions 
the NGO puts forward in governance networks are disregarded altogether by their relevant stakeholders and partners, resulting in a situation where 'there is no one who would defend the John Does on the street'.

The above quote illustrates the experts-by-experience's difficulty to express freedom in self-formation. By delineating a specific position towards one's past as 'expertise', and a specific representation of it as 'knowledge', all other forms of selfrepresentation are easily discredited. This results in a Catch-22 where an expert-byexperience can either subject herself to the demands of the project in order to be able to advance her point of view (which may longer be her point of view), or refuse to play by the rules and to construct herself freely, resulting in being shut out of the project altogether.

\section{Discussion}

In this article, I set out to illustrate the concrete practices employed to construct the participants' subjectivities in service user involvement initiatives within Finnish participatory social policy. By making the practices visible, my objective was to discern whether the participants have the possibility to practice freedom in constructing themselves within the project contexts.

Contrary to the projects' promise of creating spaces for the participants to 'develop themselves' from their own point of view, the projects were found to entail several practices that, instead, curb this freedom by setting conditions for the correct ways of working with and presenting one's story. In the context of service user involvement, it appears that one needs to be able to turn oneself into something one 'knows' rather than 'is' — and to draw the definitions of knowledge from the dominant system of thought. Consequently, the article has shown how, contrary to the projects' 
emancipatory promise, the projects' practices of self-governance can be seen as limiting the participants' freedom.

This finding supports the previous studies' suggestion that user-involvement initiatives may have a tendency to co-opt service users' knowledge, and require them to transform themselves to meet predefined norms of credible knowledge and way of being. This article has further illustrated how the projects succeed in their governance efforts. I have shown how the participants' subject-construction is influenced particularly by the projects' definitions of the appropriate process and form of 'knowing oneself'. As the experts-by-experience are expected to participate as experts of themselves, the definitions of credible knowledge can be translated into conditions the participants have to meet to be considered 'knowing themselves'.

By employing the rhetoric of knowledge and expertise, alternative ways of articulating oneself can be made to appear as 'irrational'. To refute the conditions set for expertise-by-experience would mean going against the 'normal' and the 'sane', making it easy to delegitimize attempts to advance different kinds of knowledge. This becomes clearly visible in the difficulty experienced by the experts-by-experience to have 'their own truth' accepted as part of the public discussion.

As a result, I conclude that a disconnect is apparent between, on the one hand, the participants' expectations and the promises made by the projects, and on the other, the concrete practices employed. While the projects define expertise-by-experience as 'alternative forms of knowledge' and the project environment as a site for the participants to 'freely cultivate themselves', in practice the experts-by-experience were often required to adhere to very rigid requirements regarding 'credible knowledge' in order to be accepted as 'knowing themselves'. This created a tension, as a majority of the experts-by-experience, as well as some professionals, took offence at these fixed 
definitions of knowledge, and instead entered the projects with a wish to engage in redefining what knowledge in a service user context should mean.

Such renegotiations of knowledge appear to be extremely difficult in service user involvement schemes. Although the ethos of participatory social policy is to engage multiple forms of knowledge in the decision-making, the article's findings show how the technocratic knowledge of the practitioners remains a measuring stick against which the service user's knowledge of themselves is evaluated. Consequently, the requirements of neutrality and objectivity are also used to evaluate the participants' 'expertise over themselves', resulting in a narrow and limiting way of 'being normal'. To put it bluntly, the service users are often required to connect to, and faithfully represent, the 'official truth' on themselves, instead of being accepted as the embodiments of multiple, even conflicting personal truths and diverse ways of knowing. 


\section{References}

Ball, Stephen J. and Antonio Olmedo. 2013. "Care of the Self, Resistance and Subjectivity Under Neoliberal Governmentalities." Critical Studies in Education 54 (1): 85-96. doi:10.1080/17508487.2013.740678.

Barnes, Marian. 2009. "Authoritative Consumers Or Experts by Experience? User Groups in Health and Social Care." In The Consumer in Public Services: Choice, Values and Difference, edited by Richard Simmons, Martin Powell and Ian Greener, 219-234. Bristol: Policy Press.

Barnes, Marian and Phil Cotterell. 2012a. "Introduction: From Margin to Mainstream." In Critical Perspectives on User Involvement, edited by Marian Barnes and Phil Cotterell, xv-xxvi. Bristol: Policy Press.

Barnes, Marian and Phil Cotterell. 2012b. "Introduction: User Movements." In Critical Perspectives on User Involvement, edited by Marian Barnes and Phil Cotterell, 1-5. Bristol: Policy Press.

Barnes, Marian, Janet Newman, and Helen Sullivan. 2007. Power, Participation and Political Renewal: Case Studies in Public Participation. Bristol: Policy Press. Beresford, Peter. 2002. "User Involvement in Research and Evaluation: Liberation Or Regulation?" Social Policy and Society 1 (2): 95-105. doi:10.1017/S1474746402000222.

Besley, A. C. (Tina). 2002. "Foucault and the Turn to Narrative Therapy." British Journal of Guidance \& Counselling 30 (2): 125-143. doi:10.1080/03069880220128010.

Besley, A. C. (Tina). 2005. "Self-Denial Or Self-Mastery? Foucault's Genealogy of the Confessional Self." British Journal of Guidance \& Counselling 33 (3): 365-382. doi:10.1080/03069880500179582.

Blencowe, Claire, Julian Brigstocke, and Leila Dawney. 2013. "Authority and Experience." Journal of Political Power 6 (1): 1-7. doi:10.1080/2158379X.2013.774973.

Brady, Michelle. 2014. "Ethnographies of Neoliberal Governmentalities: From the Neoliberal Apparatus to Neoliberalism and Governmental Assemblages." Foucault Studies (18): 11-33. doi://dx.doi.org/10.22439/fs.v0i18.4649.

Brady, Michelle. 2016. "Neoliberalism, Governmental Assemblages, and the Ethnographic Imaginary." In Governing Practices: Neoliberalism, 
Governmentality and the Ethnographic Imaginary, edited by Michelle Brady and Randy K. Lippert, loc. 169- loc. 988. Toronto: University of Toronto Press. Brady, Michelle. 2011. "Researching Governmentalities through Ethnography: The Case of Australian Welfare Reforms and Programs for Single Parents." Critical Policy Studies 5 (3): 264-282. doi:10.1080/19460171.2011.606300.

Brion, Fabienne and Bernard Harcourt. 2014. "The Louvain Lectures in Context." In Wrong-Doing, Truth-Telling. the Function of Avowal in Justice, edited by Fabienne Brion and Bernard Harcourt, 271-321. Chicago - Louvain-la-Neuve: University of Chicago Press - Presses universitaires de Louvain.

Charles, Julien. 2016. La Participation En Actes. Entreprise, Ville, Association. Paris:

Desclée de Brouwer.

Dagnino, Evelina. 2007. "Participation, Citizenship and Democracy: Perverse Confluence and Displacement of Meanings." In Cultures Et Pratiques Participatives. Perspectives Comparatives, edited by Catherine Neveu, 353396. Paris: L'Harmattan.

Dawney, Leila. 2011. "Social Imaginaries and Therapeutic Self-work: The Ethics of the Embodied Imagination." The Sociological Review 59 (3): 535-552. doi:10.1111/j.1467-954X.2011.02015.x.

Dean, Mitchell. 1999. Governmentality. Power and Rule in Modern Society. London: Sage.

Demszky, Alma and Armin Nassehi. 2012. "Perpetual Loss and Gain: Translation, Estrangement and Cyclical Recurrence of Experience Based Knowledges in Public Action." Policy and Society 31 (2): 169-181. doi:10.1016/j.polsoc.2012.04.006.

Eliasoph, Nina. 2016. "The Mantra of Empowerment Talk: An Essay." Journal of Civil Society 12 (3): 247-265. doi:10.1080/17448689.2016.1215895.

Faubion, James D. 2014. "Introduction: The use of Foucault." In Foucault Now: Current Perspectives in Foucault Studies, edited by James D. Faubion, 1-20. Cambridge: Polity Press.

Fledderus, Joost, Taco Brandsen, and Marlies Honingh. 2014. "Restoring Trust through the Co-Production of Public Services: A Theoretical Elaboration." Public Management Review 16 (3): 424-443. doi:10.1080/14719037.2013.848920.

Fornet-Betancourt, Raúl, Helmut Becker, and Alfredo Gomez-Müller. 1987. "The Ethic of Care for the Self as a Practice of Freedom: An Interview with Michel 
Foucault on January 20, 1984." Philosophy \& Social Criticism 12 (2-3): 112131. doi:10.1177/019145378701200202.

Foucault, Michel. 2009. Le Courage de la Vérité. Le Gouvernement de Soi et des Autres II. Cours au Collège de France 1984. Paris: Gallimard Seuil.

Foucault, Michel. 1994. Dits et Écrtis IV (1980-1988). Paris: Gallimard.

Foucault, Michel. 2012. Du Gouvernement des Vivants. Cours au Collège de France 1979-1980. Paris: Gallimard Seuil.

Foucault, Michel. 2004a. The Hermeneutics of the Subject: Lectures at the Collège de France, 1981-82. New York: Palgrave Macmillan.

Foucault, Michel. 2004b. Sécurité, Territoire, Population. Cours au Collège de France 1977-1978. Paris: Gallimard Seuil.

Foucault, Michel. 1982. "The Subject and Power." Critical Inquiry 8 (4): 777-795. https://www.jstor.org/stable/1343197?.

Fox, N. J., K. J. Ward, and A. J. O’Rourke. 2005. "The 'expert Patient': Empowerment Or Medical Dominance? the Case of Weight Loss, Pharmaceutical Drugs and the Internet." Social Science \& Medicine 60 (6): 1299-1309. doi:10.1016/j.socscimed.2004.07.005.

Fridman, Daniel. 2014. "Resisting the Lure of the Paycheck: Freedom and Dependence in Financial Self-Help." Foucault Studies 18: 90-112. doi://dx.doi.org/10.22439/fs.v0i18.4653.

Ganuza, Ernesto, Gianpaolo Baiocchi, and Nicole Summers. 2016. "Conflicts and Paradoxes in the Rhetoric of Participation." Journal of Civil Society 12 (3): 328343. doi:10.1080/17448689.2016.1215981.

Gaventa, John and Gregory Barrett. 2012. "Mapping the Outcomes of Citizen Engagement." World Development 40 (12): 2399-2410. doi:10.1016/j.worlddev.2012.05.014.

Gourgues, G., Rui, S., \& Topçu, S. (2013). Gouvernementalité et participation: Lectures critiques. Participations, 6 (2), 5-33. doi:10.3917/parti.006.0005.

Healy, Karen. 2000. Social Work Practices: Contemporary Perspectives on Change. London: Sage.

Heyes, Cressida J. 2007. Self-Transformations: Foucault, Ethics and Normalized Bodies. Oxford: Oxford University Press. 
Iftode, Cristian. 2013. "Foucault's Idea of Philosophy as 'Care of the Self:' Critical Assessment and Conflicting Metaphilosophical Views." Procedia - Social and Behavioral Sciences 71: 76-85. doi:10.1016/j.sbspro.2013.01.011.

Kelly, Mark G. E. 2009. The Political Philosophy of Michel Foucault. New York: Routledge.

Kelly, Peter. 2013. The Self as Enterprise: Foucault and the Spirit of 21st Century Capitalism. Farnham: Gower.

Krick, Eva. 2016. "The Epistemic Quality of Expertise: Contextualized Criteria for the Multi-Source, Negotiated Policy Advice of Stakeholder Fora." Critical Policy Studies: 1-18. doi:10.1080/19460171.2016.1258317.

Langer, Carol L. and Cynthia Lietz. 2014. Applying Theory to Generalist Social Work Practice. Somerset: Wiley.

Larner, Wendy and Simon Moreton. 2016. "Creating Resilient Subjects: The Coexist Project." In Governing Practices: Neoliberalism, Governmentality and the Ethnographic Imaginary, edited by Michelle Brady and Randy K. Lippert, loc. 996-loc. 1547. Toronto: Toronto University Press.

Leal, Pablo Alejandro. 2007. "Participation: The Ascendancy of a Buzzword in the Neo-Liberal Era." Development in Practice 17 (4): 539-548. doi:10.1080/09614520701469518.

Lehoux, Pascale, Genvieve Daudelin, and J. Abelson. 2012. "The Unbearable Lightness of Citizens within Public Deliberation Processes." Social Science \& Medicine 74 (12): 1843-1850. doi:10.1016/j.socscimed.2012.02.023.

Leppo, Anna and Riikka Perälä. 2009. "User Involvement in Finland: The Hybrid of Control and Emancipation." Journal of Health Organization and Management 23 (3): 359-371. doi:10.1108/14777260910966771.

Lewis, Lydia. 2010. "'It's People's Whole Lives': Gender, Class and the Emotion Work of User Involvement in Mental Health Services." Gender, Work \& Organization 19 (3): 276-305. doi:10.1111/j.1468-0432.2009.00504.x.

Li, Tania Murray. 2007a. "Governmentality." Anthropologica 49 (2): 275-294. doi:10.1146/annurev.lawsocsci.2.081805.105900.

Li, Tania Murray. 2007b. The Will to Improve. Durham: Duke University Press. Lippert, Randy K. and Michelle Brady. 2016. "Governmentalities, the Ethnographic Imaginary, and Beyond." In Governing Practices: Neoliberalism, 
Governmentality and the Ethnographic Imaginary, edited by Michelle Brady and Randy K. Lippert, loc. 6472-loc. 6592. Toronto: Toronto University Press.

Lister, Ruth. 2002. "A Politics of Recognition and Respect: Involving People with Experience of Poverty in Decision Making that Affects their Lives." Social Policy and Society 1 (1): 37-46. doi:10.1017/S1474746402001069.

Martin, Graham. 2011. "Public Deliberation in Action: Emotion, Inclusion and Exclusion in Participatory Decision Making." Critical Social Policy 32 (2): 163 183. doi:10.1177/0261018311420276.

McFalls, Laurence and Mariella Pandolfi. 2014. "Parrhesia and Therapeusis: Foucault on and in the World of Contemporary Neoliberalism." In Foucault Now. Current Perspectives in Foucault Studies, edited by James Faubion, 168-187. Cambridge: Polity Press.

McKee, Kim. 2009. "Post-Foucauldian Governmentality: What does it Offer Critical Social Policy Analysis?" Critical Social Policy 29 (3): 465-486. doi:10.1177/0261018309105180.

Närhi, Kati. 2004. The Eco-Social Approach in Social Work and the Challenges to the Expertise of Social Work. University of Jyväskylä: Jyväskylä studies in education, psychology and social research 243.

Neveu, Catherine, ed. 2007. Cultures et Pratigues Participatives. Perspectives Comparatives. Paris: L'Harmattan.

Neveu, Catherine 2011. "Just being an 'Active Citizen'? Categorisation Processes and Meanings of Citizenship in France." In Participation, Responsibility and Choice: Summoning the Active Citizen in Western European Welfare States, edited by Evelien Tonkens and Janet Newman, 147-159. Amsterdam: Amsterdam University Press.

Newman, Janet. 2005. "Participative Governance and the Remaking of the Public Sphere." In Remaking Governance: Peoples, Politics and the Public Sphere, edited by Janet Newman, 119-138. Bristol: Policy Press.

Newman, Janet and John Clarke. 2009. Publics, Politics and Power: Remaking the Public in Public Services. London: Sage.

Newman, Janet and Evelien Tonkens. 2011. "Active Citizenship: Responsibility, Choice and Participation." In Participation, Responsibility and Choice: Summoning the Active Citizen in Western European Welfare States, edited by Evelien Tonkens and Janet Newman, 179-200. Amsterdam: Amsterdam University Press. 
Nez, Héloise. 2016. "Does Participation Mean Reciprocal Learning? the Relationships between Diverse Stakeholders during Participatory Budgeting in Paris." Journal of Civil Society 12 (3): 266-281. doi:10.1080/17448689.2016.1215371.

O'Leary, Timothy. 2006. Foucault and the Art of Ethics. London: Continuum.

Perälä, Riikka. 2015. "Civil Society Organizations and Care of the Self: An Ethnographic Case Study on Emancipation and Participation in Drug Treatment." Foucault Studies 20: 96-115. doi://dx.doi.org/10.22439/fs.v0i0.4931.

Polletta, Francesca. 2016. "Participatory Enthusiasms: A Recent History of Citizen Engagement Initiatives." Journal of Civil Society 12 (3): 231-246. doi:10.1080/17448689.2016.1213505.

Powell, Jason L. and Hafiz T. A. Khan. 2012. "Foucault, Social Theory and Social Work." Sociologie Romaneasca X (1): 131-147. http://www.arsociologie.ro/en/component/content/article/21-rezumate/360powell-1-2012.

Powell, Martin, Nick Mills, Shane Doheny, and Ian Greener. 2009. "Introduction: Managing the 'unmanageable Consumer'." In The Consumer in Public Services, edited by Richard Simmons, Martin Powell and Ian Greener, 1-17. Bristol: Policy Press.

Randall, J. and I. Munro. 2010. "Foucault's Care of the Self: A Case from Mental Health Work." Organization Studies 31 (11): 1485-1504. doi:10.1177/0170840610380809.

Rissanen, Päivi. 2015. Toivoton Tapaus? Autoetnografia Sairastumisesta ja Kuntoutumisesta. Kuntoutussäätiön Tutkimuksia 88/2015. Helsinki: Kuntoutussäätiö.

Rose, Nikolas. 1999. Governing the Soul: The Shaping of the Private Self. 2nd ed. London: Free Association Books.

Rose, Nikolas, Pat O'Malley, and Mariana Valverde. 2006. "Governmentality." Annual Review of Law and Social Science 2: 83-104. doi:10.1146/annurev.lawsocsci.2.081805.105900.

Salminen, Oili and Niklas Wilhelmsson. 2013. Valtioneuvoston Demokratiapolitiikka 2002-2013. Katsaus Ministeriön Demokratiapolitiikan Toteutuksiin.

Oikeusministeriö: Selvityksiä ja ohjeita 52/2013. 
Saurugger, Sabine. 2010. "The Social Construction of the Participatory Turn: The Emergence of a Norm in the European Union." European Journal of Political Research 49 (4): 471-495. doi:10.1111/j.1475-6765.2009.01905.x.

Smith-Merry, Jennifer. 2012. "Experiential Knowledge in Action: Consulting Practitioners for Policy Change." Policy and Society 31 (2): 131-143. doi:10.1016/j.polsoc.2012.04.002.

Sørensen, Eva and Peter Triantafillou. 2009. The Politics of Self-Governance. Farnham: Routledge.

Stewart, Ellen. 2013. "A Mutual NHS? the Emergence of Distinctive Public Involvement Policy in a Devolved Scotland." Policy \& Politics 41 (2): 241-258. doi:10.1332/030557312X655404.

Teghtsoonian, Katherine. 2016. "Methods, Discourse, Activism: Comparing Institutional Ethnography and Governmentality." Critical Policy Studies 10 (3): 330-347. doi:10.1080/19460171.2015.1050426.

Tehseen, Noorani. 2013. "Service User Involvement, Authority and the 'Expert-byExperience' in Mental Health." Journal of Political Power 6 (1): 49-68. doi:10.1080/2158379x.2013.774979.

Thévenot, Laurent. 2007. "The Plurality of Cognitive Formats and Engagements." European Journal of Social Theory 10 (3): 409-423. doi:10.1177/1368431007080703.

Warren, Mark E. 2009. "Governance-Driven Democratization." Critical Policy Studies 3 (1): 3-13. doi:10.1080/19460170903158040.

Wilson, Anne and Peter Beresford. 2000. "'Anti-Oppressive Practice': Emancipation Or Appropriation?" British Journal of Social Work 30 (5): 553-573. doi:10.1046/j.1365-2524.2001.00289.x.

Wilson, Patricia M. 2001. "A Policy Analysis of the Expert Patient in the United Kingdom: Self-care as an Expression of Pastoral Power?" Health \& Social Care in the Community 9 (3): 134-142. doi:10.1046/j.1365-2524.2001.00289.x.

Yanow, Dvora. 2015. "Making Sense of Policy Practices: Interpretation and Meaning." In Handbook of Critical Policy Studies, edited by Frank Fischer, Douglas Torgerson, Anna Durnová and Michael Orsini, 401-421. Cheltenham: Edward Elgar.

Yiannoullou, Sarah. 2012. "Changing Minds: Unleashing the Potential of Mental Health Service Users - a Critical Perspective on Current Models of Service User 
Involvement and their Impact on Wellbeing and 'recovery'." In Critical

Perspectives on User Involvement, edited by Marian Barnes and Phil Cotterell, 115-128. Bristol: Policy Press. 


\section{${ }^{\mathrm{i}}$ The projects studied}

Finnish Central Association for Mental Health: Establishment of expertise-by-experience and evaluation-by-experience in the development of mental health and substance abuse services (2011-2015).

The Federation of Mother and Child Homes and Shelters: Miina - Participation and empowerment of women who have encountered domestic violence (2008-2012).

No Fixed Abode: The utilization of expertise-by-experience in the design and production of services for the homeless (2012-2015).

Muotiala Accommodation and Activity Centre Association: The project of preventive mental health work - experience-based knowledge about mental health issues for the working-age population (2005-2009).

Sininauhaliitto ry: A low-threshold information and support center for gambling problems (2010-2014).

City of Vantaa: Key to the Mind - project for developing mental health and substance abuse services in Southern Finland ${ }^{\mathrm{i}}$ (2010-2015).

City of Tampere: SOS II - To Social Inclusion through Social Work (2013-2015). 